\title{
Invited review: Phenotypes to genetically reduce greenhouse gas emissions in dairying
}

\author{
Y. de Haas, ${ }^{* 1}$ M. Pszczola, $†$ H. Soyeurt, $\ddagger$ E. Wall, $§$ and J. Lassen\# \\ *Animal Breeding and Genomics Center, Wageningen UR Livestock Research, PO Box 338, NL-6700 AH Wageningen, the Netherlands \\ †Department of Genetics and Animal Breeding, Poznan University of Life Sciences, Wolynska 33, 60-637 Poznan, Poland \\ ¥Statistics, Informatics, and Applied Modeling Unit, Department of AgroBioChem, Gembloux Agro-Bio Tech, University of Liège, \\ B-5030 Gembloux, Belgium \\ $\S$ Animal and Veterinary Sciences, Scotland's Rural College, Kings Buildings, West Mains Road, Edinburgh EH9 3JG, United Kingdom \\ \#Department of Molecular Biology and Genetics, Faculty of Science and Technology, Aarhus University, PO Box 50, DK-8830 Tjele, Denmark
}

\begin{abstract}
Phenotypes have been reviewed to select for loweremitting animals in order to decrease the environmental footprint of dairy cattle products. This includes direct selection for breath measurements, as well as indirect selection via indicator traits such as feed intake, milk spectral data, and rumen microbial communities. Many of these traits are expensive or difficult to record, or both, but with genomic selection, inclusion of methane emission as a breeding goal trait is feasible, even with a limited number of registrations. At present, methane emission is not included among breeding goals for dairy cattle worldwide. There is no incentive to include enteric methane in breeding goals, although global warming and the release of greenhouse gases is a much-debated political topic. However, if selection for reduced methane emission became a reality, there would be limited consensus as to which phenotype to select for: methane in liters per day or grams per day, methane in liters per kilogram of energy-corrected milk or dry matter intake, or a residual methane phenotype, where methane production is corrected for milk production and the weight of the cow. We have reviewed the advantages and disadvantages of these traits, and discuss the methods for selection and consequences for these phenotypes.
\end{abstract}

Key words: environmental phenotypes, greenhouse gases, enteric methane, genomic selection, dairy cattle

\section{INTRODUCTION}

Climate change is a growing international concern, and it has been well established that the release of greenhouse gases (GHG) is a contributing factor (Gerber et al., 2010). The European Union has committed

Received March 31, 2016.

Accepted October 5, 2016.

${ }^{1}$ Corresponding author: Yvette.deHaas@wur.nl to reducing its GHG emissions by $20 \%$ by 2020 relative to 1990 levels. The global livestock sector, particularly ruminants, contributes about $18 \%$ of total anthropogenic GHG emissions (Steinfeld et al., 2006). In the European Union, the livestock sector accounts for about $13 \%$ of total GHG emissions (Leip et al., 2010). Of the GHG produced by ruminants, enteric methane $\left(\mathrm{CH}_{4}\right)$ is the most important contributor, with a global warming potential 25 times that of carbon dioxide $\left(\mathrm{CO}_{2}\right)$.

The rumen is the major site of $\mathrm{CH}_{4}$ production, in which anaerobic archaeal microorganisms convert hydrogen $\left(\mathrm{H}_{2}\right)$ and $\mathrm{CO}_{2}$ to $\mathrm{CH}_{4}$. In ruminants, $\mathrm{CH}_{4}$ is a natural by-product of anaerobic respiration, produced predominantly in the rumen $(\sim 90 \%)$, and to a small extent in the large intestine ( $\sim 10 \%$; Ellis et al., 2008$)$. The contribution of $\mathrm{CH}_{4}$ released by flatulence is only marginal; eructation and air from the lungs accounts for the majority of the total $\mathrm{CH}_{4}$ produced by a ruminant. Today, $\mathrm{CH}_{4}$ emission does not have a direct economic value for the farmer, but this could change if a carbon tax was put on $\mathrm{CH}_{4}$ emissions or in relation to feed efficiency, because approximately $6 \%$ of net energy in cow feed is eructed as $\mathrm{CH}_{4}$ (Johnson et al., 1993). Reductions in $\mathrm{CH}_{4}$ emissions would not just be beneficial for the environment; it would also result in less energy lost and more efficient animals for the farmer.

Nutritional and microbial manipulation to reduce enteric $\mathrm{CH}_{4}$ emissions has been and continues to be extensively researched (Cottle et al., 2011). Animal breeding that exploits natural animal variation in $\mathrm{CH}_{4}$ emissions is an additional mitigation strategy that is inexpensive, permanent, and cumulative (Hayes et al., 2013). Still, within animal production, there has been little or no concerted effort to use long-term breeding strategies to mitigate GHG from ruminants. Several small-scale projects have been undertaken or are currently under way (mainly nationally funded), but they are too small to draw definitive conclusions or make any meaningful contribution to national breeding 
strategies (Chagunda et al., 2009; Garnsworthy et al., 2012; Lassen and Lovendahl, 2016); successful animal breeding strategies require measurements in a large population. With the recent successful incorporation of genomic information into breeding schemes, reliance on very large populations of phenotyped animals has been relaxed. Nevertheless, a reference population of several thousand animals is still needed to accurately estimate the contribution of each genomic region to the expression of the phenotype under investigation (Hayes and Goddard, 2010). Therefore, a data set of several thousand animals with similarly defined records for $\mathrm{CH}_{4}$ emissions would be sufficient for genetic evaluation of enteric $\mathrm{CH}_{4}$ emissions. Such data would also be suitable for genome-wide association studies to locate genomic regions that could influence $\mathrm{CH}_{4}$ emission from dairy cattle (Sahana et al., 2011). The actual size of a reference population for improving methane emission would depend on the desired accuracy and could be calculated using the prediction equations of Daetwyler et al. (2008) or Goddard (2009).

Measuring a trait on several thousand animals requires the trait to be easily recordable, and direct or indirect traits can be used in a selection program. The aim of this review was to provide an overview of phenotypes enabling reduction of GHG emissions in dairying through breeding, and to discuss the methods for selection and consequences for these phenotypes. We have focused on enteric $\mathrm{CH}_{4}$, as the most important contributor to GHG emissions in dairy cattle.

\section{POSSIBLE DIRECT PHENOTYPES}

Precise (and preferably inexpensive) phenotypes are needed to make genetic evaluations appropriate for traits of interest. For $\mathrm{CH}_{4}$ production, several phenotypes have been suggested (Herd et al., 2013) (Table 1). The first phenotype is methane production defined as liters or grams per day. The obvious problem selecting for this trait is that it is highly correlated with feed intake and the production trait of interest: in dairy, milk production; in sheep or beef, meat production. Another option, then, is to look at methane intensity, defined as liters of $\mathrm{CH}_{4}$ related to output [e.g., kg milk (for dairy) or meat (for sheep or beef) produced], or at methane yield, defined as liters of $\mathrm{CH}_{4}$ related to input (e.g., per $\mathrm{kg}$ of DMI). Residual methane production, defined as observed minus predicted $\mathrm{CH}_{4}$ production, has also been suggested for use (Herd et al., 2014; Berry et al., 2015; Manzanilla Pech et al., 2016). Residual methane production is based on the same concept as residual feed intake (RFI), where the phenotype of interest is regressed for each factor that influences this phenotype. For $\mathrm{CH}_{4}$, this could be milk production, body weight, or feed intake, for example. It is not necessarily obvious which of these phenotypes to select for, and it is indeed necessary to make sure that correlated information is available, so that decline in other traits is avoided when selecting for the $\mathrm{CH}_{4}$ phenotype. The most correct way might be to use methane production and include the correlation structure with milk yield, milk contents, live weight, and feed intake in the selection index. Using methane yield can create problems with double counting when setting up breeding goals, because the phenotype is adjusted, rather than running a multitrait model or including the correlated traits in an index. In beef cattle, genetic correlations between the production trait (live weight) and the several $\mathrm{CH}_{4}$ phenotypes [i.e., methane production (0.79), methane yield (0.18) and methane intensity $(-0.23)$ ] suggest that highly different responses in the production trait are possible, depending on the $\mathrm{CH}_{4}$ phenotype selected for (Donoghue et al., 2013). The same study also reported genetic correlations between methane production, methane yield, and methane intensity of 0.87 to 0.96 , using one trait or another could have a limited effect on correlated response in the production trait. However, because the study published only preliminary results, more work and collaboration is needed in this field. Also in dairy cattle, genetic correlations between the production trait (milk yield) and the $\mathrm{CH}_{4}$ phenotypes [i.e., methane production (0.43) and methane yield (0.15)] suggest that different responses in the production trait are possible, depending on the $\mathrm{CH}_{4}$ phenotype selected for (Lassen and Lovendahl, 2016).

To predict methane production (L/d), a suggested method has been to measure the concentration of $\mathrm{CH}_{4}$ and $\mathrm{CO}_{2}$ and predict daily methane production through predicted $\mathrm{CO}_{2}$ production from the weight of the fetus, the milk, and heat production (Madsen et al., 2010). This method ignores animal variation in $\mathrm{CO}_{2}$ production, but has been shown to create results that are just as precise as $\mathrm{SF}_{6}$ methodology and respiration chamber techniques (Haque et al., 2014). Another way to predict methane production is using a mobile laser methane detector (Chagunda et al., 2009). A laser methane detector is a hand-held gas detector for remote measurement of column density for $\mathrm{CH}_{4}$-containing gases. The equipment uses infrared absorption spectroscopy to establish a $\mathrm{CH}_{4}$ concentration measurement. The integrated concentration of $\mathrm{CH}_{4}$ between the equipment and the target point is displayed. The measured value is expressed as $\mathrm{CH}_{4}$ concentration, accounting for the thickness of any $\mathrm{CH}_{4}$ plume. Measurements are in parts per million-meter (ppm-m).

Many of the techniques to determine $\mathrm{CH}_{4}$ phenotypes in dairy cattle are based on short-term measurements spread over the day, indicating that only a snapshot of 
Table 1. Several methane phenotypes with their definitions, strengths, and weaknesses

\begin{tabular}{llll}
\hline Trait & Definition & Strength & Weakness \\
\hline Methane production & $\begin{array}{l}\text { Methane production per day (L/d } \\
\text { or g/d) }\end{array}$ & $\begin{array}{l}\text { The clean trait we want to } \\
\text { improve }\end{array}$ & $\begin{array}{l}\text { Highly correlated with feed } \\
\text { intake and production level }\end{array}$ \\
Methane intensity & $\begin{array}{l}\text { Methane production related to } \\
\text { output (e.g., per kg of milk, live } \\
\text { weight, meat) }\end{array}$ & $\begin{array}{l}\text { The phenotype of interest } \\
\text { for the user }\end{array}$ & $\begin{array}{l}\text { Ratio trait, so selection can be } \\
\text { difficult to incorporate properly }\end{array}$ \\
Methane yield & $\begin{array}{l}\text { Methane production related to } \\
\text { input (e.g., kg of DMI) }\end{array}$ & $\begin{array}{l}\text { The phenotype of interest } \\
\text { for the user }\end{array}$ & $\begin{array}{l}\text { Ratio trait, so selection can be } \\
\text { difficult to incorporate properly }\end{array}$ \\
Residual methane production & $\begin{array}{l}\text { Observed methane production } \\
\text { minus predicted methane } \\
\text { production }\end{array}$ & $\begin{array}{l}\text { Good statistical properties; } \\
\text { corrected for traits } \\
\text { that influence methane } \\
\text { production }\end{array}$ & $\begin{array}{l}\text { Can be difficult to explain to } \\
\text { users }\end{array}$ \\
\hline
\end{tabular}

the dairy cow's full biology is registered. It is important to be aware of this fact when generating phenotypes (Hegarty, 2013). Several factors affect methane production, including time of day, season of the year, lactation stage, herd, ration composition, and more. To predict daily methane production or lactational methane production, one needs to correct for these factors by including diurnal and herd-test-day effects in the model. This will avoid bias in the phenotype, and in the genetic prediction or variance components estimated, or both. Using the respiration chamber technique creates very precise data for a few days. It is very expensive and time-consuming, resulting in a limited number of data registrations per animal, but it can still be considered as a snapshot of an animal's full biology.

Short-term breath analyses can create registrations from many animals, but each registration lacks precision compared with the respiratory chamber technique. The calculated correlation coefficient of the laser methane detector and the calorimeter chamber was 0.8 (Chagunda and Yan, 2011). This technique will lead to lower heritability, but the potential to make repeated records. Figure 1 shows how the number of records affects the accuracy of the breeding value for a trait. Two traits are measured and analyzed. Trait 1 has a heritability of 0.05 , but data are generated using a method that is relatively easy and inexpensive to use. Trait 2 has a heritability of 0.20 , but is more expensive and timeconsuming to use. As shown in Figure 1, it is possible to achieve higher accuracy with a few (in this case 5) repeated measures of a trait and low heritability, than with just 1 record of a trait and high heritability.

\section{POSSIBLE INDIRECT PHENOTYPES}

Enteric $\mathrm{CH}_{4}$, a colorless, odorless gas, is produced predominantly in the rumen (Murray et al., 1976; Ellis et al., 2008). The conversion of feed material to
$\mathrm{CH}_{4}$ in the rumen involves the integrated activities of various microbial species, and the final step is carried out by methanogenic archaea (McAllister et al., 1996; Moss et al., 2000). The biochemical pathways among $\mathrm{CH}_{4}$, acetate, and butyrate in the rumen are common. Therefore, equations to predict $\mathrm{CH}_{4}$ from milk fatty acid composition in dairy cows have been developed in several studies (Chilliard et al., 2009; Dijkstra et al., 2011; Mohammed et al., 2011). Based on the above, an alternative to direct measurements of $\mathrm{CH}_{4}$ emission could be to use indicator traits related to $\mathrm{CH}_{4}$ production. Several studies have been conducted in this area

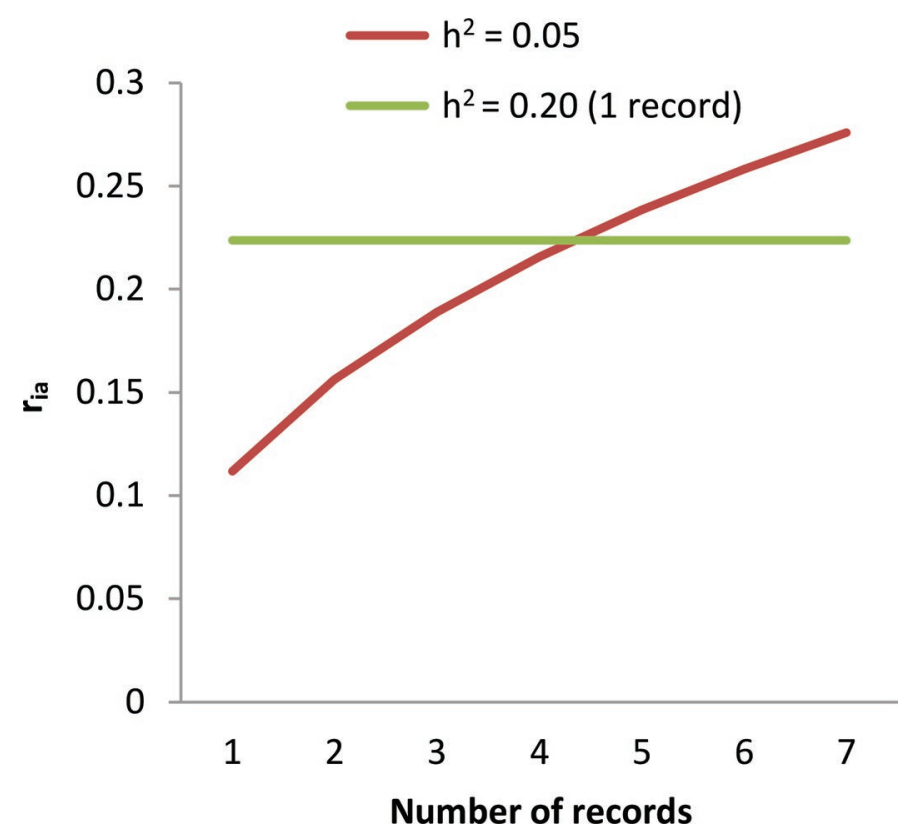

Figure 1. Accuracy $\left(r_{\text {ia }}\right)$ of 2 traits with heritabilities of 0.05 and 0.20 , where the trait with a heritability of 0.05 has repeated measurements over the lactation and the trait with a heritability of 0.20 is recorded only once. Color version available online. 
and are based on approaches, related to feed intake, microbial species in the rumen, and milk composition.

\section{Feed Intake}

Of the factors that influence $\mathrm{CH}_{4}$ emissions, feed intake accounts for most of the variation in daily $\mathrm{CH}_{4}$ emissions. Methane production and excretion from the rumen is related to feeding patterns and feeding behaviors (Johnson et al., 1998). Ingestion of a meal and subsequent fermentation increases $\mathrm{CH}_{4}$ emissions within 15 min of feeding, and elevated $\mathrm{CH}_{4}$ emissions continue for several hours. Gas production and the rate of eructation is higher soon after feeding than during rumination or resting (Colvin et al., 1958; Dougherty and Cook, 1962; McCauley and Dziuk, 1965; Waghorn and Reid, 1983). As more feed is ingested, more $\mathrm{CH}_{4}$ is produced, but the portion of $\mathrm{CH}_{4}$ per $\mathrm{kg}$ DMI decreases with increasing feed intake (Jentsch et al., 2007). The conversion of feed material to $\mathrm{CH}_{4}$ in the rumen involves the integrated activities of several different microbial species, the final step being carried out by methanogenic archaea (Attwood et al., 2011; Buddle et al., 2011; Wright and Klieve, 2011). Methane production serves as the principal electron sink in the rumen. The formation of acetate and butyrate, largely the result of fermentation of structural carbohydrate, ultimately results in the production of $\mathrm{CH}_{4}$. On the other hand, propionate, largely produced by fermentation of nonstructural carbohydrates, serves as a competitive pathway for electron use in the rumen and is accompanied by a decrease in overall $\mathrm{CH}_{4}$ production.

In addition to DMI, diet composition (e.g., dietary fat) also has an important influence in $\mathrm{CH}_{4}$ emissions (Hegarty, 2009). The amount and quality of the carbohydrate fraction affects $\mathrm{CH}_{4}$ production. For example, a greater proportion of starch reduces $\mathrm{CH}_{4}$ production, and greater fiber content increases $\mathrm{CH}_{4}$ production. Supplements capable of scavenging $\mathrm{H}_{2}$, such as unsaturated fatty acids (Martin et al., 2008) or nitrate (Hulshof et al., 2012), but also antibiotics and immunization (Buddle et al., 2011), may help to reduce ruminal $\mathrm{CH}_{4}$ production, but they may also have negative effects on feed intake and milk production.

Feeding strategies and management have a huge effect on enteric $\mathrm{CH}_{4}$ emission from dairy cattle, and intensive research has been performed in this area (Connor et al., 2012). The key nutritional factors influencing $\mathrm{CH}_{4}$ emission are the digestibility of the silage in the diet (Aguerre et al., 2010, 2011), fat sources and the content of the diet (Johannes et al., 2010), and the ratio of concentrate to silage (Aguerre et al., 2010, 2011). Several feed additives have also been suggested, such as essential oils (Benchaar and Greathead, 2011), spices
(Chaudhry and Khalil, 2010; Chaudhry and Khan, 2012), or dietary nitrate (Hulshof et al., 2012). Many of these diet changes or suggested additives have had a very negative influence on milk production, or their effect has been temporary, so that rumen microflora return to normal after a few weeks, along with $\mathrm{CH}_{4}$ emission.

Knowledge of variation in feed intake is useful for deciding the best strategy for measurement of $\mathrm{CH}_{4}$ emissions because of its dominant effect on emissions. When this knowledge is combined with a clear breeding objective and trait definition, it should be possible to work out an optimal protocol for measuring $\mathrm{CH}_{4}$ emissions. For example, if the trait under selection is methane production, some knowledge of pattern of intake is useful, but not essential for measuring $\mathrm{CH}_{4}$. However, if the trait is methane yield, we would need to know about the characteristics of feed intake as well as $\mathrm{CH}_{4}$ emissions to derive an estimate. In practice, we would need to know that correlations between feed intake and $\mathrm{CH}_{4}$ measured across time were sufficiently high, and thus useful for genetic evaluation (Pickering et al., 2013).

\section{Rumen Flora}

The digestive efficiency of the rumen of each cow depends on the microflora (microbiota) contained in its rumen. Different types of symbiotic anaerobic microorganisms, including bacteria, archaea, ciliated protozoa, and yeast, inhabit the rumen, and all play important roles in affecting the host's performance (Hungate, 1982, 1984). In fact, several small experiments have demonstrated that the microflora composition has a strong host dependency; following a complete exchange of flora between animals, they revert to the pre-exchange state over few days (Weimer et al., 2010). During development from calf to adult cow, the microflora change in distinct patterns (Li et al., 2012), and fermentation is affected by fibrous diets (Zebeli et al., 2012). More importantly, the host genome was found to influence the ruminal bacterial structure, indicating an association between the structure and diversity of rumen bacteria and cattle production efficiency (Guan et al., 2008). All these facts imply that the methanogen structure may also be associated with host (i.e., cow) genetic variation. New methods to characterize rumen microbiota (i.e., metagenomics) have evolved over recent years and offer insights and high capacity at the same time, but they generate large volumes of data (Qin et al., 2010). Tools for handling such data (e.g., bioinformatics) have been developed concurrently, but they need to be able to handle data from ruminants to be of use for agricultural purposes (Ross et al., 2012). 
Then, they would offer better opportunities for investigating host-microbe interactions (Benson et al., 2010) and their joint effects on $\mathrm{CH}_{4}$ emission, production, and efficiency traits.

\section{Milk Composition}

Milk fatty acid composition has been suggested as a means of predicting enteric $\mathrm{CH}_{4}$ output in lactating dairy cattle because of the common biochemical pathways among $\mathrm{CH}_{4}$, acetate, and butyrate in the rumen. A stoichiometric relationship between $\mathrm{CH}_{4}$ and ruminal acetate, propionate, and butyrate was proposed by Demeyer and Van Nevel (1975). These short-chain fatty acids formed in the rumen act as precursors for the de novo synthesis of milk fatty acids in mammary tissue. Methane-predictive equations from milk fatty acid composition in dairy cows have been developed in several studies (Chilliard et al., 2009; Dijkstra et al., 2011; Mohammed et al., 2011; van Lingen et al., 2014).

Recently, quantification of the fatty acid content of bovine milk has been developed using mid-infrared spectrometry (MIR) (Soyeurt et al., 2006, 2011; Rutten et al., 2009). The fatty acid prediction by MIR is feasible, and $\mathrm{CH}_{4}$ production is correlated with the milk fatty acid profile and potentially other milk components such as lactose, so there is an interest in directly quantifying the $\mathrm{CH}_{4}$ eructed by lactating cows from the milk MIR spectra. Dehareng et al. (2012) published the first article on this topic and developed an equation by combining 77 MIR milk spectra and their corresponding reference $\mathrm{SF}_{6} \mathrm{CH}_{4}$ data. This study was based on a limited number of records, but it showed the feasibility of using milk MIR spectra to evaluate the $\mathrm{CH}_{4}$ eructed by dairy cows. More recently, Vanlierde et al. (2013, 2015) confirmed these initial results from more records collected in Belgium, Ireland, and Switzerland $(\mathrm{n}=452$ $\mathrm{SF}_{6}$ records). The obtained $\mathrm{R}^{2}$ of calibration and crossvalidation were $0.76(\mathrm{R}=0.87)$ and $0.70(\mathrm{R}=0.84)$, respectively. Therefore, we can expect a relatively good robustness from MIR $\mathrm{CH}$ prediction. The $\mathrm{CH}_{4}$ information coming from milk MIR spectra can be partly related to fatty acid contents. However, the observed phenotypic correlations between the major fatty acids predicted by MIR and MIR $\mathrm{CH}_{4}$ ranged between only 0.15 and 0.30 . The highest correlations were observed, as expected, with saturated and short-chain fatty acids (Vanrobays et al., 2013). Because the correlation values were far from 1, these results confirmed interest in using direct MIR prediction of $\mathrm{CH}_{4}$ emission instead of equations using only fatty acid MIR predictions. Because MIR technology is already used by milk labs for milk payment and for routine checks of performance in dairy cows, MIR would make it possible to develop a very large database from different breeds, cows, herds, countries, and management systems.

\section{GENETIC PARAMETERS}

\section{Direct Phenotypes}

Knowledge of heritability and correlations with other traits of economic importance is necessary to include $\mathrm{CH}_{4}$ emission in breeding goals (Wall et al., 2010). We can take this further by identifying genomic regions affecting $\mathrm{CH}_{4}$ emissions in genome-wide association studies (Yu et al., 2006). To justify the investment of effort and money in developing protocols for the measurement of emissions to support genetic improvement in a $\mathrm{CH}_{4}$ trait, Pickering et al. (2015) summarized the evidence supporting this breeding strategy. Genetic diversity in a range of digestive parameters likely to be associated with enteric $\mathrm{CH}_{4}$ production was apparent when reviewed in 2004 (Hegarty, 2004). The prospect of selection for a $\mathrm{CH}_{4}$ trait was initially investigated by multiple groups; some identified variation in $\mathrm{CH}_{4}$ traits amenable to animal selection (Robinson et al., 2010), and some did not (Munger and Kreuzer, 2008). More recent research in beef (Donoghue et al., 2013) and sheep (Pinares-Patiño et al., 2011, 2013) is increasingly supportive of $\mathrm{CH}_{4}$ traits being heritable, and improvement by direct selection is achievable. Heritability (standard error in parentheses) for methane production in sheep and beef was 0.29 (0.05) and 0.40 (0.11), respectively. Heritability estimates (standard error in parenthesis) in sheep and beef for methane intensity were $0.13(0.03)$ and $0.19(0.10)$, respectively. The coefficient of phenotypic variation for both $\mathrm{CH}_{4}$ traits in sheep was 0.10 to 0.13 , suggesting that genetic variation does indeed exist. Pickering et al. (2015) showed in sheep a range in estimated heritabilities for $\mathrm{CH}_{4}$ of 0.08 to 0.38 , depending on the chosen phenotype (methane production, methane intensity, or methane yield).

Heritability estimates for methane production, methane intensity, or methane yield in dairy cows rarely exist. Just recently, a first heritability of 0.21 was published for direct methane production (Lassen and Lovendahl, 2016). Furthermore, a heritability of the ratio between $\mathrm{CH}_{4}$ and $\mathrm{CO}_{2}$ of 0.21 was documented by Lassen and Lovendahl (2013) from 683 commercial dairy cows. Methane yields predicted from milk fat composition have been demonstrated to be heritable, with heritabilities between 0.12 and 0.44 (van Engelen et al., 2015). Heritabilities estimated for predicted $\mathrm{CH}_{4}$ emissions derived from feed intake and maintenance ranged between 0.35 and 0.44 (de Haas et al., 2011; Yin et al., 2015). These heritabilities are likely given the 
heritability of DMI and live weight (Berry and Crowley, 2013).

A significant sire effect was found in an analysis of $\mathrm{CH}_{4}$ emissions during milking in 215 cows (Garnsworthy et al., 2012), suggesting a genetic component. In a Danish study with 50 Holstein and 43 Jersey cows, repeatabilities defined as the animal variance not corrected for pedigree were between 0.35 and 0.40 (Lassen et al., 2012). The majority of the studies performed so far have been on Holstein cows, but studies of Finnish Ayrshire (Negussie et al., 2012) and Jersey cows have also shown significant animal variation.

\section{Indirect Phenotypes}

Feed Intake. Methane production depends on the quantity of feed consumed, but also on the composition of the diet and dietary fat (Hegarty, 2009). The feed efficiency (i.e., RFI) of the animal may also have an effect on MP, because low-RFI cattle eat less than expected in relation to their live weight and growth rate. They are thought to use the provided resources more efficiently, producing fewer by-products (e.g., methane). Lower $\mathrm{CH}_{4}$ production by the most efficient animals (low RFI) was confirmed in an experiment comparing the $\mathrm{CH}_{4}$ emissions of Angus steers chosen from breeding lines divergently selected for RFI (Hegarty et al. (2007). The association between RFI and $\mathrm{CH}_{4}$ emission has also been shown by Nkrumah at al. (2006), where $\mathrm{CH}_{4}$ production was $28 \%$ less in low-RFI animals than in high-RFI animals.

The positive genetic correlation between predicted $\mathrm{CH}_{4}$ emission and RFI (phenotypic correlation, 0.72; genetic correlation, 0.32) suggests that selection on RFI may be one strategy for reducing $\mathrm{CH}_{4}$ emissions in ruminants (de Haas et al., 2011). Accounting for just one of these components might, however, result in undesirable genetic changes. Particular consideration must be given to the general involvement of RFI in selection strategies for dairy cows because in early lactation, they ingest insufficient feed to meet the energy requirements for milk production, and enter into negative energy balance. Severe and prolonged negative energy balance is associated with infertility in dairy cows, and this increases $\mathrm{CH}_{4}$ emissions at the herd level via increased animal numbers (Garnsworthy, 2004). Furthermore, during early lactation, dairy cows exhibit low RFI, but high feed intake is a prerequisite for minimizing the incidence of metabolic disorders such as fatty liver (Schäff et al., 2012).

MIR Predictions for $\boldsymbol{C H}_{4}$. Thanks to the use of MIR spectrometry by Walloon milk recording, a large database related to the $\mathrm{CH}_{4}$ eructed by dairy cows has been created (currently, it contains more than 3 mil- lion test-day records). This data set has permitted the study of the phenotypic and genetic variability of methane production $(\mathrm{g} / \mathrm{d})$ and methane intensity $(\mathrm{g} / \mathrm{kg}$ of fat-protein-corrected milk) predicted by MIR. Kandel et al. (2013) conducted a quantitative genetic study of MIR $\mathrm{CH}_{4}$ traits using single trait random regressions test-day models from 679,444 test-day records collected from Holstein cows in their first 3 lactations. The calculated heritability values were approximately 0.10 $\mathrm{g} / \mathrm{d}$ for methane production $(0.12,0.10$, and 0.09 for the first, second, and third parity, respectively). Methane intensity was slightly more heritable, with values around 0.15 (0.18, 0.12 , and 0.14 for cows in their first 3 lactations). These results suggest a relatively moderate heritability of methane production by dairy cows. However, by using animal-selection strategies, the gain would be cumulative and permanent, and after several years could have a significant effect on the global $\mathrm{CH}_{4}$ emission of dairy cows.

Positive genetic correlations were observed between MIR-predicted methane production (in $\mathrm{g} / \mathrm{d}$ ) and fatand protein-corrected milk, fat yield, and protein yield (Kandel et al., 2013). This means that a decrease of $\mathrm{CH}_{4}$ should have negative effects on milk, fat, and protein yields. However, for many years, breeding selection has not been based solely on milk production, but also on other traits combined in a breeding selection index. Studying the effect of the introduction of the MIR $\mathrm{CH}_{4}$ trait in the breeding selection index is therefore interesting. Kandel et al. (2014) investigated the consequences of selection for traits of environmental impact in dairy cows. These authors used methane intensity ( $\mathrm{g} / \mathrm{kg}$ of milk) and calculated the approximate genetic correlation from estimated breeding values. They observed negative approximate genetic correlations between methane intensity and milk yield $(-0.67)$, fat yield $(-0.13)$, protein yield $(-0.46)$, longevity $(-0.07)$, and average of conformation traits $(-0.23)$. They observed positive approximate correlations for fertility (0.31) and body condition score (0.27). Based on these correlations and with a hypothetical $25 \%$ weight on methane intensity in the current Walloon genetic evaluation index, the results suggested that a decrease of methane intensity could have a negative effect on cow fertility but a positive effect on longevity. However, the weight of methane intensity used by these authors was not fixed based on economic aspects, because no clear economic value exists at this time for the $\mathrm{CH}_{4}$ trait.

A first attempt at performing an economic analysis of breeding schemes to reduce the environmental impact of milk production was done by Hansen Axelsson et al. (2015). They simulated several breeding goal scenario and used a deterministic approach with a gene flow method and a selection index procedure to test 
the scenarios. The breeding goal consisted of 3 traitsmilk production, functional traits, and environmental impact-with economic values of $€ 83$, €82, and €83, respectively. These economic values were set following the study by Buch et al. (2012b), in which economic values were calculated so that the correlation between the simulated breeding goal and methane production was equal to the correlation between the Nordic total merit and the milk production index. Based on these assumptions, the break-even price for measuring $\mathrm{CH}_{4}$ emissions from eructed air was calculated to be $€ 29$ per record in the reference population (Hansen Axelsson et al., 2015). The availability of these economic incentives could better define the weight, and then the consequences of selection could be better appreciated.

\section{BREEDING GOAL}

\section{What Trait in the Breeding Goal?}

One of the prerequisites for making genetic progress with a quantitative trait is that the trait has an economic value. Today, $\mathrm{CH}_{4}$ emission has no economic value, and is not included in any breeding scheme (Boichard and Brochard, 2012). It might not be realistic to assume that the price for carbon will rise to a level that justifies the inclusion of $\mathrm{CH}_{4}$ emission in breeding goals, but the agricultural community might choose to put a non-market value on this trait to obtain social acceptance for producing milk and meat (Boichard and Brochard, 2012). To reduce $\mathrm{CH}_{4}$ emissions from dairy cattle, Wall et al. (2010) announced 3 pathways that could help: improved efficiency; reduced waste, such as involuntary culling or empty recycling periods; and direct response on emissions by measuring the trait or correlated traits. Improving efficiency would lead to less $\mathrm{CH}_{4}$ per kilogram of milk produced (i.e., methane intensity), simply because fewer cows are needed to produce the same amount of milk. Reducing waste would have a similar effect: for example, lowering the age at first calving would imply that the cow would start sooner "paying off" the energy she consumed and the $\mathrm{CH}_{4}$ she produced as young stock. The first 2 pathways are mainly a dilution effect, which has been mentioned in other studies (Capper et al., 2009; Knapp et al., 2014), whereas the third pathway is truly a reduction in $\mathrm{CH}_{4}$ production. However, it is important to know the effect of direct selection for lower $\mathrm{CH}_{4}$ emission to avoid a decline in other traits in the breeding goal, such as production, reproduction, and health. So far, very few genetic correlations have been estimated between $\mathrm{CH}_{4}$ emission and other traits. In a simulation study, a negative genetic correlation of 0.2 between functional traits and $\mathrm{CH}_{4}$ emission was assumed, as environmental impact was used with a negative genetic correlation between milk production and environmental impact (Axelsson-Hansen et al., 2013). This study showed that it was possible to get an improvement for environmental impact of 20 to $34 \%$ at the cost of a decline in milk production of $7 \%$ and in functional traits of $5 \%$. Wall et al. (2010) also used a negative genetic correlation between reproduction and $\mathrm{CH}_{4}$ emission in a breeding scheme.

Many production and fitness traits have been shown to have a genetic component and have scope for improvement via genetic selection. Current broader breeding goals that select for both production and fitness traits can help to mitigate GHG from many livestock systems. In many cases, this can be achieved simply through selection for production traits. Reducing the number of animals required to produce a fixed level of output reduces the GHG (including $\mathrm{CH}_{4}$ ) produced per unit product. For example, the dairy sector in Canada has reduced its methane emissions by $10 \%$ since 1990 by reducing the number of animals (Désilets, 2006). Selection for fitness traits (lifespan, health, fertility) helps to reduce emissions by reducing waste of animals. Improving lifespan in dairy cows reduces waste by reducing the number of followers. For example, by improving lifespan in dairy cows from 3.02 to 3.5 lactations will reduce methane emissions by $3 \%$ (Wall et al., 2012). Improving health and fertility will reduce involuntary culling rates and lower emissions from dairy systems by reducing the number of followers required. Improving fertility will reduce calving/lambing intervals and inseminations, resulting in shorter dry/unproductive periods, lowering management costs as well as emissions. Improving health reduces incidence of health problems/diseases, thereby improving animal welfare, reducing treatment costs (and lower antibiotic use), and reducing emissions by maintaining the productivity level of the animal (which is reduced during periods of poor health). Garnsworthy (2004) used modeling to estimate that if cow fertility was restored from 2003 levels to 1995 levels, that methane production from the dairy industry would decrease by 10 to $15 \%$. Improving calving and maternal traits would reduce emissions by improving the survival of offspring during the peri-, neo-, and postnatal periods. This would reduce waste in a farming system, decreasing overall emissions as well as improving calf and dam welfare and survival.

\section{Developing New Traits for Inclusion in Broader Breeding Goals}

Feed Utilization Efficiency in Ruminants. Feed utilization has been considered in selection programs for pig and poultry species for many years. Due to the 
nature of many ruminant production systems, with less opportunity for intensive feed intake recording, the use of such traits in selection has been limited, but there have been some examples. Herd et al. (2002) and Hegarty (2009) showed decreased methane production in animals selected for reduced RFI. Reduced RFI is akin to selection for high feed efficiency, because an animal is eating less but maintaining a similar growth rate (high net feed efficiency), so less feed is required to produce a unit of output. Lines were divergently selected for high and low RFI and showed no significant differences for most production traits. This shows that it is possible to select for reduced GHG emissions by selecting animals that use less feed and produce less methane to achieve a given level of performance.

Efficiency of Absorption of Dietary Nutrients. Direct selection for efficiency of utilization of diet components is difficult to achieve, because many animal and feed parameters would need to be collected. Work on these types of traits has mainly been at an experimental level. Ferris et al. (1999) showed that mediumgenetic-merit (for production) Holstein-Friesian cows have higher nitrogen and $\mathrm{CH}_{4}$ emissions per unit of $\mathrm{N}$ and gross energy intake, respectively, than highgenetic-merit cows. This suggests that high-geneticmerit cows convert the energy and protein components of the feed more effectively than medium-genetic-merit cows. Hegarty (2004) reviewed the evidence for a genetic difference in gut function in ruminants, covering genetic components of factors such as diet selection and eating rate, digestive kinetics, and MP. The data suggested genetic differences in methane intensity (i.e., the amount of $\mathrm{CH}_{4}$ produced per unit feed intake). Further examination of the metabolic turnover of nutrients in animals may be required to understand the underlying biological differences in feed utilization between highproducing animals and lower-genetic-merit animals. Other metabolic traits that require further examination due to their effect on emissions include water dynamics (manure consistency), gut function (nutrient and mineral absorption), and litter quality.

Direct Measures of Methane. Direct selection for reduced GHG emissions would ideally be based on direct measurement of $\mathrm{CH}_{4}$ emissions. Direct measurement of all sources of $\mathrm{CH}_{4}$ emissions from individual animals (exhaled by the animal due to enteric fermentation, flatulence, and to a lesser extent from manure) may prove difficult. However, $\mathrm{CH}_{4}$ emitted by individuals or groups of animals can be measured, and these data can be analyzed in different ways. Variation has been reported between animals, between breeds, and across time (Herd et al., 2002; Garnsworthy et al., 2012; Lassen et al., 2012), providing potential for improvement through genetic selection. Development of new direct and indirect measurement techniques will help to enhance the ability to reduce emissions through genetic selection.

\section{Developing New Indices to Include GHG Reductions}

Broader breeding goals have become the norm in many livestock species, usually incorporating production and "fitness" (health, fertility, longevity) traits. Breeding goals can be built in several ways, including the popular method of weighting traits by their relative economic value (Wall, 2010). Relative economic values tend to be calculated by estimating the economic disadvantage/benefit of a unit change in the traits being examined. Many of the example traits given earlier have been incorporated into indices for particular livestock sectors. However, livestock industries have more recently needed to consider societal views of farming systems, including issues such as welfare, biodiversity, food safety, health properties, and the environment.

Noneconomic Selection Indices. Taking societal views into account in the economic framework of selection indices can be difficult, because there may be no clear and direct monetary return from such considerations. Using restricted or desired gains approaches allow weightings to be derived that will see the desired response in traits of interest. The difficulty in the restricted/desired gains index methodology is developing a robust way of deciding on the desired outcomes of the selection index. Because selection considers the longerterm changes in a system, the desired outcomes of selection cannot change year on year. Another method would be to use an economic index framework, but to use new methodology to calculate economic weights for traits that have no clear direct market value. Such contingent valuation methods have been suggested by Nielsen and Amer (2007) and von Rohr (1999), who suggested methods of calculating economic values using market research approaches such as conjoint analysis, which asks consumers to assign preferences for the differing components of the product. This method would allow public perception to be included when deriving economic weights that aim to reduce emissions from farming systems.

Environmental Indices. Many traits described earlier, including those routinely included in current selection indices, have an indirect environmental impact; therefore, the effect of a change in these traits can be expressed in an environmental impact unit such as global warming potential or carbon equivalents (e.g., lifespan example given earlier). Farm models have been used to evaluate the emissions from a livestock system and the effect that a change in a trait (e.g., fertility) would have on overall emissions. This approach is simi- 
lar to the framework used to estimate relative environmental values, and weightings derived could be used as an environmental selection index (Wall et al., 2010; van Middelaar et al., 2014).

Interactions with the System. Although focus of this paper is on the development of genetic improvement tools to reduce $\mathrm{CH}_{4}$ emissions, there is undoubtedly a large nutritional component, with a great deal of research into the differences between diets for $\mathrm{CH}_{4}$ emissions and the use of additives to diets to reduce emissions (Moss et al., 2000; Martin et al., 2010). However, little work has been done on the potential role of genetics on emissions, particularly considering their role in the whole farming system and its interaction with feeding strategy and management policies (e.g., energy balance, housing periods, fertilization, and manure management). Robertson and Waghorn (2002) showed a genotype $\times$ environment (diet) interaction on $\mathrm{CH}_{4}$ emissions from dairy systems, with United States genotypes producing 8 to $11 \%$ less $\mathrm{CH}_{4}$ as a percentage of gross energy intake than New Zealand genotypes on both pasture and TMR diets.

Selection indices have tended to be expressed in terms of a generalized system representative of the "average" dairy farm. However, there will be a difference in emissions and economics depending on the production systems and the animals used within those systems (i.e., an animal of a particular genotype will perform differently in a high-input system than in a low-input system; Bell et al., 2011). The system parameters and relative economics will also differ by production type. For example, recent work has shown that the economics of body tissue mobilization differs depending on the calving system employed (spring vs. autumn), due to the different costs of feed for grazing compared with winter feeding (Wall et al., 2008). Differences in environmental impact are also possible, related to tissue use and waste, depending on system types. In developing environmental indices, it will be important to consider the different systems to help farmers consider the longterm environmental impact of their choice of breeding animals, specific to their system of production. For example, in dairy cows, is it better in environmental terms to gather and preserve feed for winter feeding, or for cows to store some of that energy as body lipid and then use it during the winter? Is it more efficient for the cow to produce milk with low solids content ready for direct consumption, or for factories to alter milk with high solids content to suit intended use? The answer to these and similar questions may dictate the type of dairy cow for the future.

Overall, the outlook for GHG mitigation in agriculture has significant potential. Current initiatives suggest that synergy between climate change policies, sustainable development, and improvement of environmental quality will lead the way forward to realize the mitigation potential in the sector.

\section{GENOMIC SELECTION}

Use of SNP genetic markers in animal improvement enables selection for novel traits. To establish prediction equations, SNP are combined with phenotypic information collected on a group of animals called a reference population (Meuwissen et al., 2001). Then, based on the prediction equations, genotyped animals without phenotypic information can be evaluated. Finally, best individuals are selected for breeding based on this evaluation. This process has been called genomic selection. Genomic selection, contrary to conventional selection, relaxes the need to collect many phenotypes to achieve genetic progress. Instead, genetic progress is conditional on the accuracy of the genomic predictions, which depends on the reference population size, among other factors (Meuwissen et al., 2001; Goddard and Hayes, 2009; Hayes et al., 2009). Collecting many phenotypes for difficult-to-measure or expensive traits is challenging; additional efforts must be taken to increase the accuracy of prediction, including the following: optimizing the reference population with respect to the relationships between the animals; incorporating ungenotyped but phenotyped animals into the reference population; using reference populations with females' own phenotypes, instead of progeny-based sires' reference population; combining data sets internationally; and incorporating predictor traits into analyses.

\section{Relationships}

The accuracy of genomic predictions depends on the relationships between animals. The closer the selection candidates are related to the reference population, the higher the accuracy that can be achieved (Habier et al., 2010; Wolc et al., 2011; Clark et al., 2012; Pszczola et al., 2012), and the more genetically diverse the reference population (Clark et al., 2012; Pszczola et al., 2012), the higher the accuracy of genomic prediction (see Figure 2). A more diverse reference population means that more usable variation in the population can be captured. Phenotypes on relatives, however, give more information about the selection candidate than information from unrelated individuals. Thus, setup of a reference population for reducing $\mathrm{CH}_{4}$ emissions through selective breeding could be an optimal solution.

\section{Ungenotyped Animals}

Usually the reference population consists of genotyped animals with phenotypes. However, some animals 


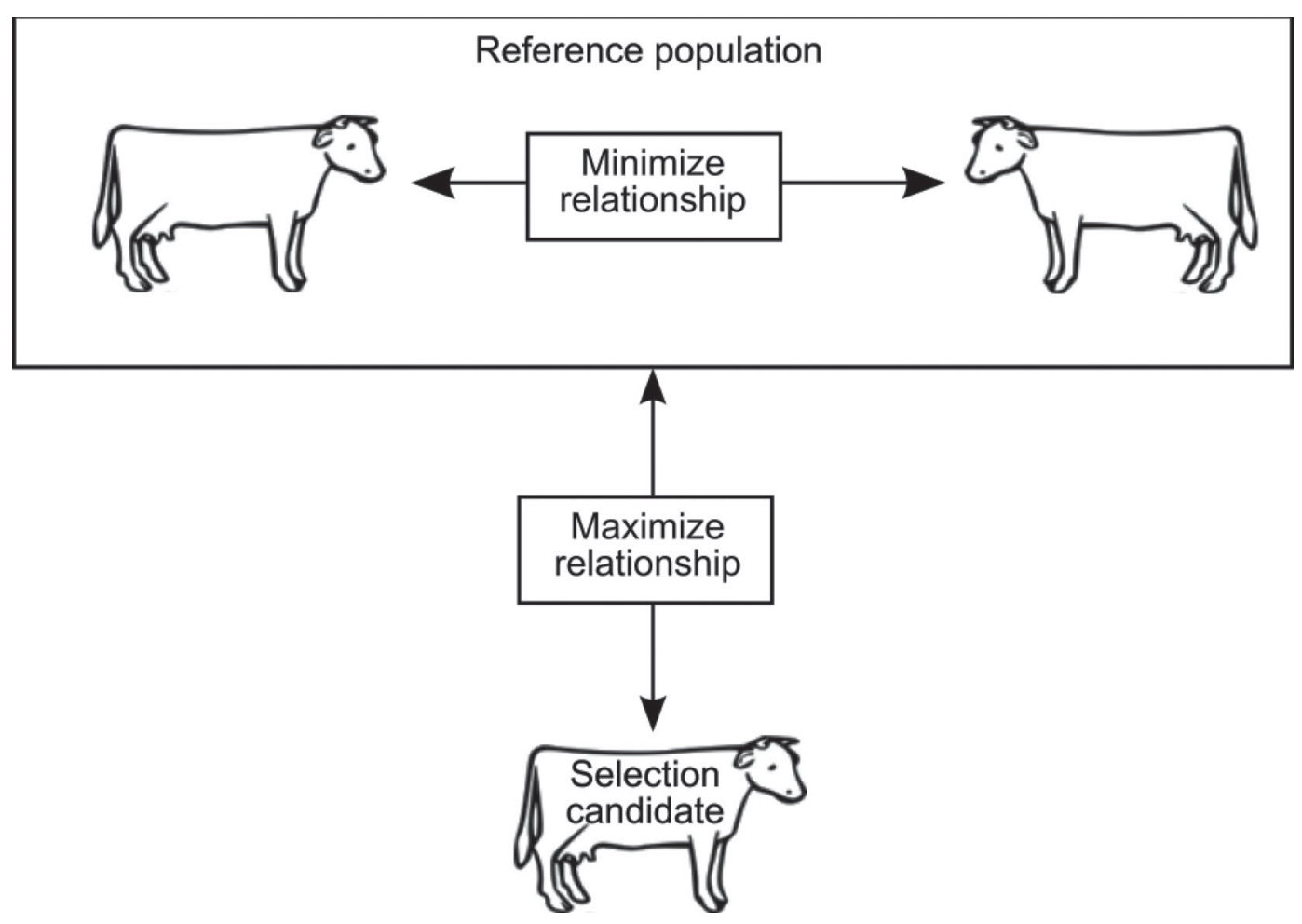

Figure 2. Optimal design of the reference population for reducing methane emissions through genomic selection (source: Pszczola, 2013).

that were phenotyped but not genotyped can also contribute to the reference population. If the phenotypes come from old experiments, then they may have to be adjusted so that they are comparable with currently collected phenotypes. Traits definitions also have to be verified and adjusted if necessary.

Ungenotyped animals can be included in genomic evaluation by combining pedigree and genomic information in a joint relationship matrix (Legarra et al., 2009; Aguilar et al., 2010), or by imputing the missing genotypes using pedigree information (Gengler et al., 2008; Lund et al., 2010; Pszczola et al., 2011), linkage information ( $\mathrm{Li}$ and Abecasis, 2006; Scheet and Stephens, 2006; Howie et al., 2009), or both (Druet and Georges, 2010; Daetwyler et al., 2011; Hickey et al., 2012).

The important aspect of imputation is its accuracy, because it is linearly related to the accuracy of the genomic prediction established using ungenotyped animals (Mulder et al., 2012). Inaccurately imputed genotypes do not increase genomic prediction accuracy and will not increase genetic progress for novel traits (Pszczola et al., 2011). Imputation accuracy has been shown to depend on the parameters characterizing the population (e.g., effective population size) and the number of close relatives genotyped (Boettcher et al., 2004; Calus et al., 2011). Bouwman et al. (2014) showed that imputation accuracy can reach 0.92 when an ungenotyped animal has 4 offspring. Also, predicting the genotype of a dam was accurate ( 0.81 to 0.93 ) when genotypes were available for the dam's sire, 1 offspring and this offspring's sire, along with estimates of marker allele frequencies (Pimentel et al., 2013). The authors showed that the improvement in the genomic prediction accuracy could be up to $37 \%$. The effect of including ungenotyped animals in the reference population, next to imputation accuracy, depends on trait heritability, population structure, and the initial size of the reference population. It seems to be a promising solution, especially for small reference populations and when the considered trait is less heritable.

\section{Female Reference Population}

The reference population of routinely recorded traits usually consists of bulls with very accurate phenotypes derived on many daughters. Progeny-based records, however, require at least 5 times more phenotypes than progeny-based records for low to moderate heritability $(<0.8)$, and above this threshold 10 offspring per progeny-based record are required to reach the accuracy of the single phenotype observed on the reference animal (Pszczola, 2013). Indeed, de Roos (2011) suggested that using records based on 100 progeny requires about 


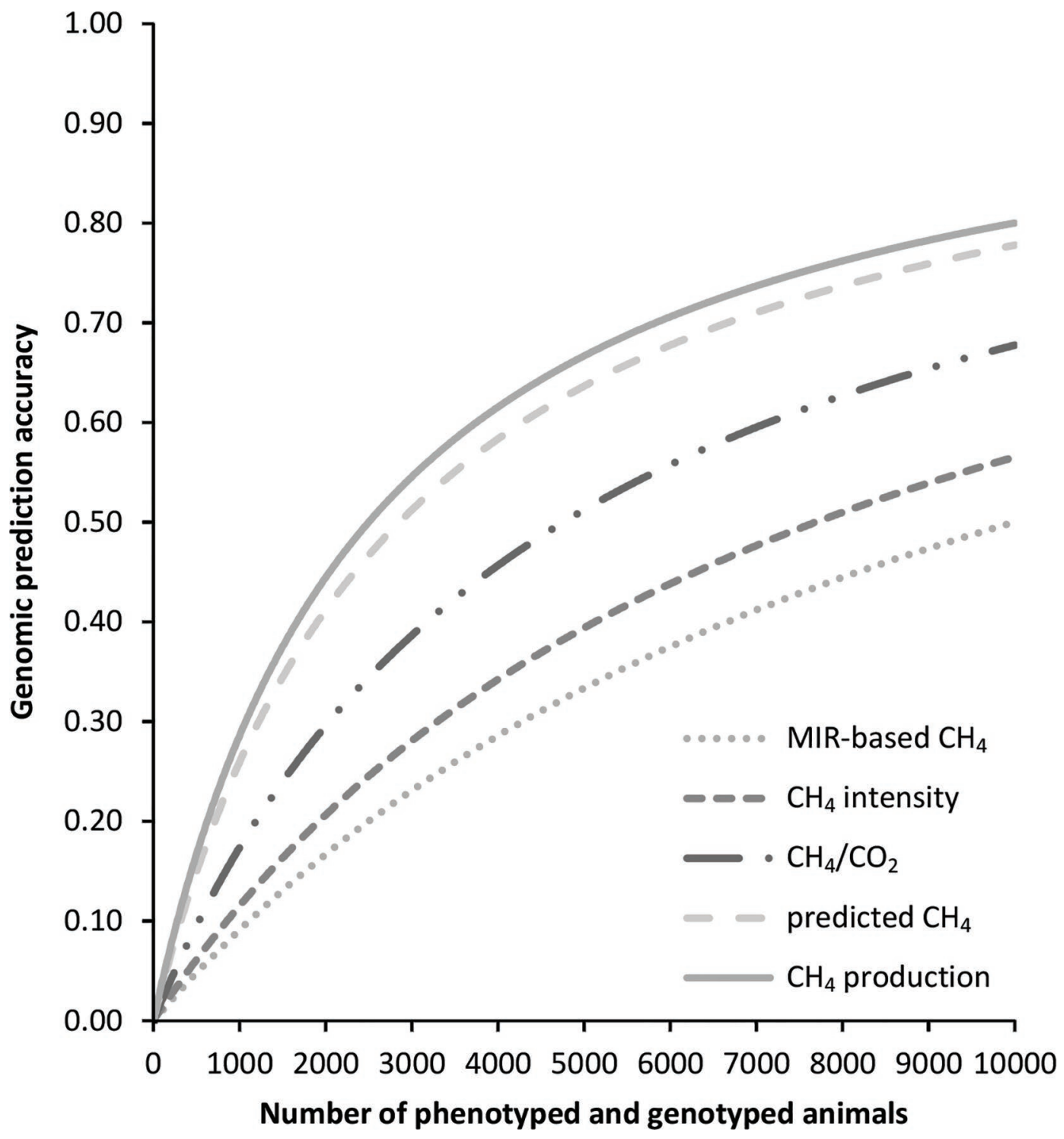

Figure 3. Relationship between genomic prediction accuracy and the number of phenotyped and genotyped animals for different methane $\left(\mathrm{CH}_{4}\right)$ phenotypes: (1) Mid-infrared spectroscopy (MIR)-based $\mathrm{CH}_{4}$, emission (g/d) based on MIR milk analyses; $(2) \mathrm{CH}_{4}$ intensity, emission per kilogram of feed intake; (3) $\mathrm{CH}_{4} / \mathrm{CO}_{2}$, ratio of methane to carbon dioxide; (4) predicted $\mathrm{CH}_{4}$, based on feed intake and maintenance; (5) $\mathrm{CH}_{4}$ production, total production (in beef). For heritability estimates, measuring methods, and sources of information, see Pickering et al. (2013). Genomic prediction accuracy was based on Daetwyler et al. (2008), with effective chromosome segments of 1,000 following Wientjes et al. (2013).

15 to 50 times as many records as the own phenotype. When only a few offspring can be phenotyped per animal, it is better to use the offspring themselves as the reference animals (Buch et al., 2012a; Van Grevenhof et al., 2012; Pszczola, 2013). Methane-emission phenotypes are very likely to be scarcely recorded in the near future, so the reference population for this trait should be based on female records. Given the heritability of $\mathrm{CH}_{4}$ phenotypes ranging from 0.1 to 0.4 (Pickering et al., 2013), the number of phenotypic records needed to reach an appropriate accuracy will depend of the choice of the phenotyping technique (Figure 3 ).

\section{Combined Reference Population}

Gathering a large reference population for a difficultto-measure or expensive trait is certainly not achievable for a single country or even a small group of countries. However, when researchers in many countries are collecting the phenotypic information, individual reference populations can be joined to create a population of sufficient size. This has become possible due to recent developments in genomic selection, where countries share genomic reference populations (Lund et al., 2011; Pryce et al., 2014) and a focus is placed on genotyping fe- 
males to improve reference populations (de Haas et al., 2012). Combining data sets from herds or countries is, however, challenging. It requires adjusting phenotypes so they are comparable across locations (e.g., Banos et al., 2012). The factors affecting the traits must be accounted for, and the protocols for collecting the data must be unified. When data are collected using different protocols, combining them is not a trivial undertaking; it requires intensive consultation among contributing scientists across a range of disciplines. Nevertheless, combining data sets from different countries has been a successful strategy for novel traits such as DMI (de Haas et al., 2012; Berry et al., 2015) and could be applied for $\mathrm{CH}_{4}$ emission. At this time, however, $\mathrm{CH}_{4}$ emission is measured using different methods, and scientists planning to undertake studies in $\mathrm{CH}_{4}$ have not yet agreed on protocols for how to combine these data. This is an important step to be taken before data sets can be combined and used for joint benefit.

\section{Predictor Traits}

When traits of interest are genetically related, change in one trait will cause change in another. Using correlated traits may, therefore, be beneficial for improving difficult-to-measure or expensive traits. Such predictor trait(s) must be easily accessible and inexpensive to record, but most importantly (preferably) highly correlated with the trait of interest $(>0.5$; Calus and Veerkamp, 2011). Predictor traits can be recorded not only for reference animals for the difficult trait, but also for a separate set of animals: for example, on the national reference population (Calus et al., 2013a,b). Another study showed that using predictor traits in a multitrait genomic framework can lead to an increase in the accuracy of genomic predictions when selection candidates are phenotyped or not phenotyped for the predictor trait and the correlation between the traits used in the analyses is sufficiently high ( $>0.5$; Calus and Veerkamp, 2011). The highest benefit for using predictor traits in studies by Pszczola et al. (2013) was found when predictor traits were recorded both for the selection candidates and the reference population.

\section{FUTURE PERSPECTIVES}

\section{Genomic Selection}

The current phenotyping technology for $\mathrm{CH}_{4}$ emission restricts the number of measured animals. Overcoming this restriction is the main priority for $\mathrm{CH}_{4}$ emission and other novel traits. Presently, given a fixed budget, genotyping with a $50 \mathrm{k}(\sim 50,000)$ SNP chip is recommended. Alternatively, a lower-density SNP chip can be used if the imputation accuracy from low-density to $50 \mathrm{k}$ is accurate $(>0.80)$ (Pszczola, 2013). When the costs of genotyping with high-density SNP chips are lower and phenotyping techniques are more available, it may be worthwhile to consider using sequence data. Sequence data are believed to enable evaluation across breeds, which would enable increases in the reference population size by including data collected on various breeds and lead to an increase in the accuracy of predictions. However, research on across-breed evaluation still has not brought an answer on how to apply this concept in practice. With sequence data, causal mutations may also be identified. Knowing the actual genes that lead to increased $\mathrm{CH}_{4}$ emission could lead to a selection scheme targeted to avoid the selected genes. However, this hypothesis must be verified before considering it for application.

Genetic progress for difficult-to-measure or expensive traits is possible, thanks to wide application of genomic selection and developing the optimization techniques useful especially for small reference populations. Many studies focusing on further optimization of genomic selection promise even higher genetic gains for novel traits in the future. Meanwhile, focus needs to be on improving phenotyping.

\section{Genetic Evaluation}

To undertake genetic evaluation and ranking of animals for $\mathrm{CH}_{4}$ emission, it is crucial to create registries for commercial farms. To make that possible, it will be necessary to develop phenotypes that can be used by farmers to optimize production at a farm level. It will also be crucial to develop equipment the makes it possible to create registries without interfering with everyday routines.

International collaboration is essential to make progress in this area, to share ideas, experiences, and phenotypes, but also to reach consensus on what phenotype to collect and to select for. Methods to handle data from small-scale phenotyping to large-scale genomic breeding needs to be developed further to ensure that registries being created around the globe will be used at the farm level.

\section{ACKNOWLEDGMENTS}

This review is based partly on the development of knowledge reached in the networks of COST Action FA1302 "Large-scale methane measurements on individual ruminants for genetic evaluations" and the Animal Selection, Genetics and Genomics Network of the Livestock Research Group of the Global Research Alliance on Agricultural Greenhouse Gases. The au- 
thors are grateful for support from the European Science Foundation, providing for the COST office, and to all scientists contributing to the development work in this network. This research was partly financed within NCN OPUS 2013/09/B/NZ9/03179; Marcin Pszczola acknowledges the financial support of Polish Ministry of Science and Higher Education. Jan Lassen acknowledges the Sapere Aude program under the Independent Danish Research Council Technology and Production (Project no 11-105913). Yvette de Haas acknowledges the financial support of Breed4Food (BO-22.04-011001-ASG-LR).

\section{REFERENCES}

Aguerre, M. J., M. A. Wattiaux, J. M. Powell, and G. A. Broderick. 2010. Effect of dietary forage to concentrate ratio on lactation performance and methane emission from dairy cows. In Proc. 4th Int. Conf. GHG Anim. Agric., Banff, Canada.

Aguerre, M. J., M. A. Wattiaux, J. M. Powell, G. A. Broderick, and C. Arndt. 2011. Effect of forage-to-concentrate ratio in dairy cow diets on emission of methane, carbon dioxide, and ammonia, lactation performance, and manure excretion. J. Dairy Sci. 94:3081-3093.

Aguilar, I., I. Misztal, D. L. Johnson, A. Legarra, S. Tsuruta, and T. J. Lawlor. 2010. Hot topic: A unified approach to utilize phenotypic, full pedigree, and genomic information for genetic evaluation of Holstein final score. J. Dairy Sci. 93:743-752.

Attwood, G. T., E. Altermann, W. J. Kelly, S. C. Leahy, L. Zhang, and M. Morrison. 2011. Exploring rumen methanogen genomes to identify targets for methane mitigation strategies. Anim. Feed Sci. Technol. 166-67:65-75.

Axelsson, H. H., W. F. Fikse, M. Kargo, A. C. Sorensen, K. Johansson, and L. Rydhmer. 2013. Genomic selection using indicator traits to reduce the environmental impact of milk production. J. Dairy Sci. 96:5306-5314.

Banos, G., M. P. Coffey, R. F. Veerkamp, D. P. Berry, and E. Wall. 2012. Merging and characterising phenotypic data on conventional and rare traits from dairy cattle experimental resources in three countries. Animal 6:1040-1048.

Bell, M. J., E. Wall, G. Russell, G. Simm, and A. W. Stott. 2011. The effect of improving cow productivity, fertility, and longevity on the global warming potential of dairy systems. J. Dairy Sci. 94:3662-3678.

Benchaar, C., and H. Greathead. 2011. Essential oils and opportunities to mitigate enteric methane emissions from ruminants. Anim. Feed Sci. Technol. 166-67:338-355.

Benson, A. K., S. A. Kelly, R. Legge, F. R. Ma, S. J. Low, J. Kim, M. Zhang, P. L. Oh, D. Nehrenberg, K. J. Hua, S. D. Kachman, E. N. Moriyama, J. Walter, D. A. Peterson, and D. Pomp. 2010. Individuality in gut microbiota composition is a complex polygenic trait shaped by multiple environmental and host genetic factors. Proc. Natl. Acad. Sci. USA 107:18933-18938.

Berry, D. P., and J. J. Crowley. 2013. Cell biology symposium: Genetics of feed efficiency in dairy and beef cattle. J. Anim. Sci. 91:1594-1613.

Berry, D. P., J. Lassen, and Y. de Haas. 2015. Residual feed intake and breeding approached for enteric methane. Pages 273-291 in Livestock Production and Climate Change. P. K. Malik, R. Bhatta, J. Takahashi, R. A. Kohn, and C. S. Prasad, ed. CABI, Wallingford, UK.

Boettcher, P. J., G. Pagnacco, and A. Stella. 2004. A Monte Carlo approach for estimation of haplotype probabilities in half-sib families. J. Dairy Sci. 87:4303-4310.

Boichard, D., and M. Brochard. 2012. New phenotypes for new breeding goals in dairy cattle. Animal 6:544-550.

Bouwman, A. C., J. Hickey, M. Calus, and R. Veerkamp. 2014. Imputation of non-genotyped individuals based on genotyped relatives:
Assessing the imputation accuracy of a real case scenario in dairy cattle. Genet. Sel. Evol. 46:6.

Buch, L. H., M. Kargo, P. Berg, J. Lassen, and A. C. Sørensen. 2012a. The value of cows in reference populations for genomic selection of new functional traits. Animal 6:880.

Buch, L. H., M. K. Sorensen, P. Berg, L. D. Pedersen, and A. C. Sorensen. 2012b. Genomic selection strategies in dairy cattle: Strong positive interaction between use of genotypic information and intensive use of young bulls on genetic gain. J. Anim. Breed. Genet. 129:138-151.

Buddle, B. M., M. Denis, G. T. Attwood, E. Altermann, P. H. Janssen, R. S. Ronimus, C. S. Pinares-Patino, S. Muetzel, and D. N. Wedlock. 2011. Strategies to reduce methane emissions from farmed ruminants grazing on pasture. Vet. J. 188:11-17.

Calus, M. P. L., Y. De Haas, M. Pszczola, and R. F. Veerkamp. 2013a. Predicted accuracy of and response to genomic selection for new traits in dairy cattle. Animal 7:183-191.

Calus, M. P., Y. de Haas, and R. F. Veerkamp. 2013b. Combining cow and bull reference populations to increase accuracy of genomic prediction and genome-wide association studies. J. Dairy Sci. 96:6703-6715.

Calus, M. P. L., and R. F. Veerkamp. 2011. Accuracy of multi-trait genomic selection using different methods. Genet. Sel. Evol. 43:26.

Calus, M. P. L., R. F. Veerkamp, and H. A. Mulder. 2011. Imputation of missing single nucleotide polymorphism genotypes using a multivariate mixed model framework. J. Anim. Sci. 89:2042-2049.

Capper, J. L., R. A. Cady, and D. E. Bauman. 2009. The environmental impact of dairy production: 1944 compared with 2007. J. Anim. Sci. 87:2160-2167.

Chagunda, M. G. G., D. Ross, and D. J. Roberts. 2009. On the use of a laser methane detector in dairy cows. Comput. Electron. Agric. $68: 157-160$

Chagunda, M. G. G., and T. Yan. 2011. Do methane measurements from a laser detector and an indirect open-circuit respiration calorimetric chamber agree sufficiently closely? Anim. Feed Sci. Technol. 165:8-14.

Chaudhry, A. S., and M. A. K. Khalil. 2010. Effect of various spices on in vitro degradability, methane and fermentation profiles of different ruminant feeds. In Proc. 4th Int. Conf. GHG Anim. Agric., Banff, Canada.

Chaudhry, A. S., and M. M. H. Khan. 2012. Impacts of different spices on in vitro rumen dry matter disappearance, fermentation and methane of wheat or ryegrass hay based substrates. Livest. Sci. 146:84-90.

Chilliard, Y., C. Martin, J. Rouel, and M. Doreau. 2009. Milk fatty acids in dairy cows fed whole crude linseed, extruded linseed, or linseed oil, and their relationship with methane output. J. Dairy Sci. 92:5199-5211.

Clark, S. A., J. Hickey, H. Daetwyler, and J. van der Werf. 2012. The importance of information on relatives for the prediction of genomic breeding values and the implications for the makeup of reference data sets in livestock breeding schemes. Genet. Sel. Evol. 44:4.

Colvin, H. W., P. T. Cupps, and H. H. Cole. 1958. Dietary influences on eructation and related ruminal phenomena in cattle. J. Dairy Sci. 41:1565-1579.

Connor, E. E., J. L. Hutchison, K. M. Olson, and H. D. Norman. 2012. Triennial lactation symposium: Opportunities for improving milk production efficiency in dairy cattle. J. Anim. Sci. 90:1687-1694.

Cottle, D. J., J. V. Nolan, and S. G. Wiedemann. 2011. Ruminant enteric methane mitigation: A review. Anim. Prod. Sci. 51:491-514.

Daetwyler, H. D., B. Villanueva, and J. A. Woolliams. 2008. Accuracy of predicting the genetic risk of disease using a genome-wide approach. PLoS One 3:e3395.

Daetwyler, H. D., G. R. Wiggans, B. J. Hayes, J. A. Woolliams, and M. E. Goddard. 2011. Imputation of missing genotypes from sparse to high density using long-range phasing. Genetics 189:317-327.

de Haas, Y., M. P. L. Calus, R. F. Veerkamp, E. Wall, M. P. Coffey, H. D. Daetwyler, B. J. Hayes, and J. E. Pryce. 2012. Improved accuracy of genomic prediction for dry matter intake of dairy cattle from combined European and Australian data sets. J. Dairy Sci. 95:6103-6112. 
de Haas, Y., J. J. Windig, M. P. L. Calus, J. Dijkstra, M. de Haan, A. Bannink, and R. F. Veerkamp. 2011. Genetic parameters for predicted methane production and potential for reducing enteric emissions through genomic selection. J. Dairy Sci. 94:6122-6134.

de Roos, A. P. W. 2011. Genomic Selection in Dairy Cattle. Wageninen University, Wageningen, Netherlands.

Dehareng, F., C. Delfosse, E. Froidmont, H. Soyeurt, C. Martin, N. Gengler, A. Vanlierde, and P. Dardenne. 2012. Potential use of milk mid-infrared spectra to predict individual methane emission of dairy cows. Animal 6:1694-1701.

Demeyer, D. I., and C. J. Van Nevel. 1975. Methanogenesis, an integrated part of carbohydrate fermentation and its control. Pages 366-382 in Digestion and Metabolism in the Ruminant. I. W. McDonald and A. C. I. Warner, ed. University of New England Publishing Unit, Armidale, NSW, Australia.

Désilets, E. 2006. Greenhouse gas mitigation program for Canadian agriculture. Final report for the Dairy Farmers of Canada. Accessed Oct. 29, 2016. http://www.dairyfarmers.ca/content/ download/307/1692/version/1/file/Our_cows_our_air_final_ report.pdf.

Dijkstra, J., S. M. van Zijderveld, J. A. Apajalahti, A. Bannink, W. J. J. Gerrits, J. R. Newbold, H. B. Perdok, and H. Berends. 2011. Relationships between methane production and milk fatty acid profiles in dairy cattle. Anim. Feed Sci. Technol. 166-67:590-595.

Donoghue, K. A., R. M. Herd, S. H. Bird. P. F. Arthur, and R. S. Hegarty. 2013. Preliminary genetic parameters for methane production in Australian beef cattle. Pages 290-293 in 20th Proc. Assoc. Advmt. Anim. Breed. Genet., Napier, New Zealand. http:// www.aaabg.org/aaabghome/proceedings20.php.

Dougherty, R. W., and H. M. Cook. 1962. Routes of eructed gas expulsion in cattle-A quantitative study. Am. J. Vet. Res. 23:997-1000.

Druet, T., and M. Georges. 2010. A hidden Markov model combining linkage and linkage disequilibrium information for haplotype reconstruction and quantitative trait locus fine mapping. Genetics 184:789-798

Ellis, J. L., J. Dijkstra, E. Kebreab, A. Bannink, N. E. Odongo, B. W. McBride, and J. France. 2008. Aspects of rumen microbiology central to mechanistic modelling of methane production in cattle. J. Agric. Sci. 146:213-233.

Ferris, C. P., F. J. Gordon, D. C. Patterson, M. G. Porter, and T. Yan. 1999. The effect of genetic merit and concentrate proportion in the diet on nutrient utilization by lactating dairy cows. J. Agric. Sci. 132:483-490.

Garnsworthy, P. C. 2004. The environmental impact of fertility in dairy cows: A modelling approach to predict methane and ammonia emissions. Anim. Feed Sci. Technol. 112:211-223.

Garnsworthy, P. C., J. Craigon, J. H. Hernandez-Medrano, and N Saunders. 2012. Variation among individual dairy cows in methane measurements made on farm during milking. J. Dairy Sci. 95:3181-3189.

Gengler, N., S. Abras, C. Verkenne, S. Vanderick, M. Szydlowski, and R. Renaville. 2008. Accuracy of prediction of gene content in large animal populations and its use for candidate gene detection and genetic evaluation. J. Dairy Sci. 91:1652-1659.

Gerber, P., N. Key, F. Portet, and H. Steinfeld. 2010. Policy options in addressing livestock's contribution to climate change. Animal 4:393-406.

Goddard, M. 2009. Genomic selection: Prediction of accuracy and maximisation of long term response. Genetica 136:245-257.

Goddard, M. E., and B. J. Hayes. 2009. Mapping genes for complex traits in domestic animals and their use in breeding programmes. Nat. Rev. Genet. 10:381-391.

Guan, L. L., J. D. Nkrumah, J. A. Basarab, and S. S. Moore. 2008 Linkage of microbial ecology to phenotype: Correlation of rumen microbial ecology to cattle's feed efficiency. FEMS Microbiol. Lett. 288:85-91.

Habier, D., J. Tetens, F.-R. Seefried, P. Lichtner, and G. Thaller. 2010. The impact of genetic relationship information on genomic breeding values in German Holstein cattle. Genet. Sel. Evol. 42:5-17.

Hansen Axelsson, H., J. R. Thomasen, A. C. Sørensen, L. Rydhmer, M. Kargo, K. Johansson, and W. F. Fikse. 2015. Breakeven prices for recording of indicator traits to reduce the environmental impact of milk production. J. Anim. Breed. Genet. 132:30-41.

Haque, M. N., C. Cornou, and J. Madsen. 2014. Estimation of methane emission using the C02 method from dairy cows fed concentrate with different carbohydrate compositions in automatic milking system. Livest. Sci. 164:57-66.

Hayes, B., and M. Goddard. 2010. Genome-wide association and genomic selection in animal breeding. Genome 53:876-883.

Hayes, B. J., P. J. Bowman, A. J. Chamberlain, and M. E. Goddard. 2009. Invited review: Genomic selection in dairy cattle: Progress and challenges. J. Dairy Sci. 92:433-443.

Hayes, B. J., H. A. Lewin, and M. E. Goddard. 2013. The future of livestock breeding: genomic selection for efficiency, reduced emissions intensity, and adaptation. Trends Genet. 29:206-214.

Hegarty, R. S. 2004. Genotype differences and their impact on digestive tract function of ruminants: A review. Aust. J. Exp. Agric. 44:458-467.

Hegarty, R. S. 2009. Current and emerging technologies for decreasing enteric methane emission from individual ruminants. Rec. Adv. Anim. Nutr. 17:81-88

Hegarty, R. S. 2013. Applicability of short-term emission measurements for on-farm quantification of enteric methane. Animal 7:401-408

Hegarty, R. S., J. P. Goopy, R. M. Herd, and B. McCorkell. 2007. Cattle selected for lower residual feed intake have reduced daily methane production. J. Anim. Sci. 85:1479-1486.

Herd, R. M., P. F. Arthur, S. H. Bird, K. A. Donoghue, and R. S. Hegarty. 2014. Genetic variation for methane traits in beef cattle. In Proc. 10th World Conference on Genetic Applied to Livestock Production, Vancouver, Canada. https://asas.org/meetings/ previous-meetings/wcgalp.

Herd, R. M., P. F. Arthur, R. S. Hegarty, and J. A. Archer. 2002. Potential to reduce greenhouse gas emissions from beef production by selection for reduced residual feed intake. In Proc. 7th World Congress on Genetics Applied to Livestock Production, Montpellier, France.

Herd, R. M., S. H. Bird, K. A. Donoghue, P. F. Arthur, and R. S. Hegarty. 2013. Phenotypic associations between methane production traits, volatile fatty acids and animal breeding traits. Pages 286-289 in Proc. Proc. Assoc. Advmt. Anim. Breed. Genet., Napier, New Zealand.

Hickey, J. M., B. Kinghorn, B. Tier, J. van der Werf, and M. Cleveland. 2012. A phasing and imputation method for pedigreed populations that results in a single-stage genomic evaluation. Genet. Sel. Evol. 44:9.

Howie, B. N., P. Donnelly, and J. Marchini. 2009. A flexible and accurate genotype imputation method for the next generation of genome-wide association studies. PLoS Genet. 5:e1000529.

Hulshof, R. B. A., A. Berndt, W. J. J. Gerrits, J. Dijkstra, S. M. van Zijderveld, J. R. Newbold, and H. B. Perdok. 2012. Dietary nitrate supplementation reduces methane emission in beef cattle fed sugarcane-based diets. J. Anim. Sci. 90:2317-2323.

Hungate, R. E. 1982. Methane formation and cellulose digestionBiochemical ecology and microbiology of the rumen ecosystem. Experientia 43:117-120.

Hungate, R. E. 1984. Symposium on 'Nutritional implications of microbial action in the nonruminal alimentary tract'. Microbes of nutritional importance in the alimentary tract. Proc. Nutr. Soc. 43:1-11.

Jentsch, W., M. Schweigel, F. Weissbach, H. Scholze, W. Pitroff, and M. Derno. 2007. Methane production in cattle calculated by the nutrient composition of the diet. Arch. Anim. Nutr. 61:10-19.

Johannes, M., A. L. F. Hellwing, P. Lund, M. R. Weisbjerg, and T. Hvelplund. 2010. Different physical forms of rapeseed as fat source to reduce enteric methane emission from dairy cows. In Proc. Proc. 4th. Int. Conf. GHG Anim. Agric., Banff, Canada.

Johnson, D. E., T. M. Hill, G. M. Ward, K. A. Johnson, M. E. Branine, B. R. Carmean, and D. W. Lodman. 1993. Ruminants and other animals. Pages 199-229 in Atmospheric Methane: Sources, Sinks, and Role in Global Change. Vol. 13. M. A. K. Khalil, ed Springer, Berlin, Germany. 
Johnson, K. A., H. H. Westberg, B. K. Lamb, and R. L. Kincaid. 1998. The use of sulphur hexafluoride for measuring methane production by cattle. Pages 189-192 in Energy Metabolism of Farm Animals. K. J. McCracken, E. F. Unsworth, and A. R. G. Wylie, ed. CABI Publishing, Wallingford, UK.

Kandel, P. B., S. Vanderick, M.-L. Vanrobays, A. Vanlierde, F. Dehareng, E. Froidmont, H. Soyeurt, and N. Gengler. 2014. Consequences of selection for environmental impact traits in dairy cows. In Proc. 10th World Conference on Genetic Applied to Livestock Production, Vancouver, Canada, August 17-22, 2014.

Kandel, P. B., M.-L. Vanrobays, A. Vanlierde, F. Dehareng, E. Froidmont, P. Dardenne, E. Lewis, F. Buckley, M. H. Deighton, S. McParland, N. Gengler, and H. Soyeurt. 2013. Genetic parameters for methane emissions predicted from milk mid-infrared spectra in dairy cows. Adv. Anim. Biosci. 4:279.

Knapp, J. R., G. L. Laur, P. A. Vadas, W. P. Weiss, and J. M. Tricarico. 2014. Invited review: Enteric methane in dairy cattle production: Quantifying the opportunities and impact of reducing emissions. J. Dairy Sci. 97:3231-3261.

Lassen, J., and P. Lovendahl. 2013. Heritability for enteric methane emission from Danish Holstein cows using a non-invasive FTIR method. Adv. Anim. Biosci. 4:280.

Lassen, J., and P. Lovendahl. 2016. Heritability estimates for enteric methane emissions from Holstein cattle measured using noninvasive methods. J. Dairy Sci. 99:1959-1967.

Lassen, J., P. Lovendahl, and J. Madsen. 2012. Accuracy of noninvasive breath methane measurements using Fourier transform infrared methods on individual cows. J. Dairy Sci. 95:890-898.

Legarra, A., I. Aguilar, and I. Misztal. 2009. A relationship matrix including full pedigree and genomic information. J. Dairy Sci. 92:4656-4663.

Leip, A., F. Weiss, T. Wassenaar, I. Perez, T. Fellmann, P. Loudjani, F. Tubiello, D. Grandgirard, S. Monni, and K. Biala. 2010. Evaluation of the livestock sector's contribution to the EU greenhouse gas emissions (GGELS) - final report. Accessed Oct. 29, 2016. http://ec.europa.eu/agriculture/analysis/external/ livestock-gas/full_text_en.pdf.

Li, R. W., E. E. Connor, C. J. Li, R. L. Baldwin, and M. E. Sparks 2012. Characterization of the rumen microbiota of pre-ruminant calves using metagenomic tools. Environ. Microbiol. 14:129-139.

Li, Y., and G. R. Abecasis. 2006. Mach 1.0: rapid haplotype reconstruction and missing genotype inference. Am. J. Hum. Genet. 79:2290.

Lund, M. S., A. P. W. de Roos, A. G. de Vries, T. Druet, V. Ducrocq, S. Fritz, F. Guillaume, B. Guldbrandtsen, Z. T. Liu, R. Reents, C. Schrooten, F. Seefried, and G. S. Su. 2011. A common reference population from four European Holstein populations increases reliability of genomic predictions. Genet. Sel. Evol. 43:43.

Lund, M. S., A. P. W. de Roos, A. G. de Vries, T. Druet, V. Ducroq, S. Fritz, F. Guillaume, B. Guldbrandtsen, Z. Liu, R. Reents, C. Schrooten, M. Seefried, and G. Su. 2010. Improving genomic prediction by EuroGenomics collaboration. In Proc. 9th World Congress on Genetics Applied to Livestock Production, Leipzig, Germany.

Madsen, J., B. S. Bjerg, T. Hvelplund, M. R. Weisbjerg, and P. Lund. 2010. Methane and carbon dioxide ratio in excreted air for quantification of the methane production from ruminants. Livest. Sci. 129:223-227.

Manzanilla Pech, C. I. V., Y. De Haas, B. J. Hayes, R. F. Veerkamp, M. Khansefid, K. A. Donoghue, P. F. Arthur, and J. E. Pryce. 2016. Genome-wide association study of methane emissions in Angus beef cattle with validation in dairy cattle. J. Anim. Sci. 94:4151-4166.

Martin, C., D. P. Morgavi, and M. Doreau. 2010. Methane mitigation in ruminants: From microbe to the farm scale. Animal 4:351-365.

Martin, C., J. Rouel, J. P. Jouany, M. Doreau, and Y. Chilliard. 2008. Methane output and diet digestibility in response to feeding dairy cows crude linseed, extruded linseed, or linseed oil. J. Anim. Sci. $86: 2642-2650$.

McAllister, T. A., E. K. Okine, G. W. Mathison, and K. J. Cheng. 1996. Dietary, environmental and microbiological aspects of methane production in ruminants. Can. J. Anim. Sci. 76:231-243.
McCauley, E. H., and H. E. Dziuk. 1965. Correlation of motility and gas collection from goat rumen. Am. J. Physiol. 209:1152.

Meuwissen, T. H., B. Hayes, and M. Goddard. 2001. Prediction of total genetic value using genome-wide dense marker maps. Genetics 157:1819-1829.

Mohammed, R., S. M. McGinn, and K. A. Beauchemin. 2011. Prediction of enteric methane output from milk fatty acid concentrations and rumen fermentation parameters in dairy cows fed sunflower, flax, or canola seeds. J. Dairy Sci. 94:6057-6068.

Moss, A. R., J. P. Jouany, and J. Newbold. 2000. Methane production by ruminants: Its contribution to global warming. Ann. Zootech. 49:231-253.

Mulder, H. A., M. P. L. Calus, T. Druet, and C. Schrooten. 2012 Imputation of genotypes with low-density chips and its effect on reliability of direct genomic values in Dutch Holstein cattle. J. Dairy Sci. 95:876-889

Munger, A., and M. Kreuzer. 2008. Absence of persistent methane emission differences in three breeds of dairy cows. Aust. J. Exp. Agric. 48:77-82.

Murray, R. M., A. M. Bryant, and R. A. Leng. 1976. Rates of production of methane in rumen and large-intestine of sheep. Br. J. Nutr. $36: 1-14$.

Negussie, E., A.-E. Liinamo, P. Mantysaari, E. Mantysaari, and M. Lidauer. 2012. Between and within-individual variation in methanee output measurements in dairy cows. Page 170 in Proc. European Association of Animal Production, Bratislava, Slovakia.

Nielsen, H. M., and P. R. Amer. 2007. An approach to derive economic weights in breeding objectives using partial profile choice experiments. Animal 1:1254-1262.

Nkrumah, J. D., E. K. Okine, G. W. Mathison, K. Schmid, C. Li, J. A Basarab, M. A. Price, Z. Wang, and S. S. Moore. 2006. Relationships of feedlot feed efficiency, performance, and feeding behavior with metabolic rate, methane production, and energy partitioning in beef cattle. J. Anim. Sci. 84:145-153.

Pickering, N. K., Y. De Haas, J. A. Basarab, K. Cammack, B. J. Hayes, R. S. Hegarty, J. Lassen, J. C. McEwan, S. Miller, C. Pinares, G. Shackell, P. Vercoe, and V. H. Oddy. 2013. Consensus methods for breeding low emitting animals. Animal Selection Genetics Genomics Network white paper. Accessed Oct. 29, 2016. http://www. asggn.org/publications,listing, 95,mpwg-white-paper.html.

Pickering, N. K., V. H. Oddy, J. A. Basarab, K. Cammack, B. J. Hayes, R. S. Hegarty, J. C. McEwan, S. Miller, C. Pinares, and Y. De Haas. 2015. Invited review: Genetic possibilities to reduce enteric methane emissions from ruminants. Animal 9:1431-1440. https://doi.org/10.1017/S1751731115000968.

Pimentel, E. C., M. Wensch-Dorendorf, S. Konig, and H. Swalve. 2013. Enlarging a training set for genomic selection by imputation of ungenotyped animals in populations of varying genetic architecture. Genet. Sel. Evol. 45:12.

Pinares-Patiño, C. S., S. M. Hickey, E. A. Young, K. G. Dodds, S. MacLean, G. Molano, E. Sandoval, H. Kjestrup, R. Harland, C. Hunt N. K. Pickering, and J. C. McEwan. 2013. Heritability estimates of methane emissions from sheep. Animal 7:316-321.

Pinares-Patiño, C. S., J. C. McEwan, K. G. Dodds, E. A. Cardenas, R. S. Hegarty, J. P. Koolaard, and H. Clark. 2011. Repeatability of methane emissions from sheep. Anim. Feed Sci. Technol. $166-67: 210-218$

Pryce, J. E., J. Johnston, B. J. Hayes, G. Sahana, K. A. Weigel, S. McParland, D. Spurlock, N. Krattenmacher, R. J. Spelman, E. Wall, and M. P. L. Calus. 2014. Imputation of genotypes from low density (50,000 markers) to high density (700,000 markers) of cows from research herds in Europe, North America, and Australasia using 2 reference populations. J. Dairy Sci. 97:1799-1811.

Pszczola, M. 2013. Optimizing Genomic Selection for Scarcely Recorded Traits. Wageningen UR, Wageningen, Netherlands.

Pszczola, M., H. A. Mulder, and M. P. L. Calus. 2011. Effect of enlarging the reference population with (un)genotyped animals on the accuracy of genomic selection in dairy cattle. J. Dairy Sci. 94:431-441. 
Pszczola, M., T. Strabel, H. A. Mulder, and M. P. L. Calus. 2012. Reliability of genomic selection for animals with different relationships within and to the reference population. J. Dairy Sci. 95:389-400.

Pszczola, M., R. F. Veerkamp, Y. de Haas, E. Wall, T. Strabel, and M. P. L. Calus. 2013. Effect of predictor traits on accuracy of genomic breeding values for feed intake based on a limited cow reference population. Animal 7:1759-1768.

Qin, J., R. Li, J. Raes, M. Arumugam, K. S. Burgdorf, C. Manichan, T. Nielsen, N. Pons, F. Levenez, T. Yamada, D. R. Mende, J. Li, J. Xu, S. Li, D. Li, J. Cao, B. Wang, H. Liang, H. Zheng, Y. Xie, J. Tap, P. Lepage, M. Bertalan, J. M. Batto, T. Hansen, D. le Paslier, A. Linneberg, H. B. Nielsen, E. Pelletier, P. Renault, T. Sicheritz-Ponten, K. Turner, H. Zhu, C. Yu, S. Li, M. Jian, Z. Yan, Y. Li, X. Zhang, S. Li, N. Qin, H. Yang, J. Wang, S. Brunak, J. Doré, F. Guarner, K. Kristiansen, O. Pedersen, J. Parkhill, J. WeissenbachMetaHIT Consortium, P. Bork, S. D. Ehrlich, and J. Wang. 2010. A human gut microbial gene catalogue established by metagenomic sequencing. Nature 464:59-65.

Robertson, L. J., and G. C. Waghorn. 2002. Dairy industry perspectives on methane emissions and production from cattle fed pasture or total mixed rations in New Zealand. Pages 213-218 in Proc. New Zealand Soc. Animal Production, Palmerston North, New Zealand. http://www.nzsap.org/view/biblio/volume/62.

Robinson, D. L., J. P. Goopy, R. S. Hegarty, and P. Vercoe. 2010. Repeatability, animal and sire variation in 1-hr methane emissions and relationships with rumen volatile fatty acid concentrations. Page 712 in 9th World Congress on Genetics Applied to Livestock Production. Leipzig, Germany.

Ross, E. M., P. J. Moate, C. R. Bath, S. E. Davidson, T. I. Sawbridge, K. M. Guthridge, B. G. Cocks, and B. J. Hayes. 2012. High throughput whole rumen metagenome profiling using untargeted massively parallel sequencing. BMC Genet. 13:53.

Rutten, M. J. M., H. Bovenhuis, K. A. Hettinga, H. J. F. van Valenberg, and J. A. M. van Arendonk. 2009. Predicting bovine milk fat composition using infrared spectroscopy based on milk samples collected in winter and summer. J. Dairy Sci. 92:6202-6209.

Sahana, G., T. Mailund, M. S. Lund, and B. Guldbrandtsen. 2011. Local genealogies in a linear mixed model for genome-wide association mapping in complex pedigreed populations. PLoS One 6:e27061.

Schäff, C., S. Borner, S. Hacke, U. Kautzsch, D. Albrecht, H. M. Hammon, M. Rontgen, and B. Kuhla. 2012. Increased anaplerosis, TCA cycling, and oxidative phosphorylation in the liver of dairy cows with intensive body fat mobilization during early lactation. J. Proteome Res. 11:5503-5514.

Scheet, P., and M. Stephens. 2006. A fast and flexible statistical model for large-scale population genotype data: Applications to inferring missing genotypes and haplotypic phase. Am. J. Hum. Genet. $78: 629-644$.

Soyeurt, H., P. Dardenne, F. Dehareng, G. Lognay, D. Veselko, M. Marlier, C. Bertozzi, P. Mayeres, and N. Gengler. 2006. Estimating fatty acid content in cow milk using mid-infrared spectrometry. J. Dairy Sci. 89:3690-3695.

Soyeurt, H., F. Dehareng, N. Gengler, S. McParland, E. Wall, D. P. Berry, M. Coffey, and P. Dardenne. 2011. Mid-infrared prediction of bovine milk fatty acids across multiple breeds, production systems, and countries. J. Dairy Sci. 94:1657-1667.

Steinfeld, H., P. Gerber, T. Wassenaar, V. Castel, M. Rosales, and C. de Haan. 2006. Livestock's Long Shadow: Environmental Issues and Options. Food and Agriculture Organization of the United Nations, Rome, Italy.

van Engelen, S., H. Bovenhuis, J. Dijkstra, J. A. M. van Arendonk, and M. Visker. 2015. Short communication: Genetic study of methane production predicted from milk fat composition in dairy cows. J. Dairy Sci. 98:8223-8226.

Van Grevenhof, E. M., J. Van Arendonk, and P. Bijma. 2012. Response to genomic selection: The Bulmer effect and the potential of genomic selection when the number of phenotypic records is limiting. Genet. Sel. Evol. 44:26.

van Lingen, H. J., L. A. Crompton, W. H. Hendriks, C. K. Reynolds, and J. Dijkstra. 2014. Meta-analysis of relationships between enteric methane yield and milk fatty acid profile in dairy cattle. J. Dairy Sci. 97:7115-7132.

van Middelaar, C. E., P. B. M. Berentsen, J. Dijkstra, J. A. M. van Arendonk, and I. J. M. de Boer. 2014. Methods to determine the relative value of genetic traits in dairy cows to reduce greenhouse gas emissions along the chain. J. Dairy Sci. 97:5191-5205.

Vanlierde, A., F. Dehareng, E. Froidmont, P. Dardenne, P. B. Kandel, N. Gengler, M. H. Deighton, F. Buckley, E. Lewis, S. McParland, D. P. Berry, and H. Soyeurt. 2013. Prediction of the individual enteric methane emission of dairy cows from milk-mid-infrared spectra. Adv. Anim. Biosci. 4:433.

Vanlierde, A., M. L. Vanrobays, F. Dehareng, E. Froidmont, H. Soyeurt, S. McParland, E. Lewis, M. H. Deighton, F. Grandl, M. Kreuzer, B. Gredler, P. Dardenne, and N. Gengler. 2015. Hot topic: Innovative lactation-stage-dependent prediction of methane emissions from milk mid-infrared spectra. J. Dairy Sci. 98:5740-5747.

Vanrobays, M.-L., P. B. Kandel, H. Soyeurt, A. Vanlierde, F. Dehareng, E. Froidmont, and N. Gengler. 2013. Phenotypic and genetic variability of methane emissions and milk fatty acid contents of Walloon Holstein dairy cattle. Page 33 in Proc. 19th Natl. Symposium on Applied Biological Sciences, Gembloux, Belgium. http://www.events.gembloux.ulg.ac.be/nsabs2014/.

von Rohr, P., A. Hofer, and N. Kunzi. 1999. Economic values for meat quality traits in pigs. J. Anim. Sci. 77:2633-2640.

Waghorn, G. C., and C. S. W. Reid. 1983. Rumen motility in sheep and cattle given different diets. N. Z. J. Agric. Res. 26:289-295.

Wall, E. 2010. Broadening breeding goals in a changing world. In World Conf. Genet. Applied Livest. Prod., Leipzig, Germany.

Wall, E., M. P. Coffey, and P. R. Amer. 2008. A theoretical framework for deriving direct economic values for body tissue mobilization traits in dairy cattle. J. Dairy Sci. 91:343-353.

Wall, E., M. P. Coffey, and G. E. Pollott. 2012. The effect of lactation length on greenhouse gas emissions from the national dairy herd. Animal 6:1857-1867.

Wall, E., G. Simm, and D. Moran. 2010. Developing breeding schemes to assist mitigation of greenhouse gas emissions. Animal 4:366-376.

Weimer, P. J., D. M. Stevenson, H. C. Mantovani, and S. L. C. Man. 2010. Host specificity of the ruminal bacterial community in the dairy cow following near-total exchange of ruminal contents. J. Dairy Sci. 93:5902-5912.

Wientjes, Y. C. J., R. F. Veerkamp, and M. P. L. Calus. 2013. The effect of linkage disequilibrium and family relationships on the reliability of genomic prediction. Genetics 193:621-631.

Wolc, A., J. Arango, P. Settar, J. E. Fulton, N. P. O'Sullivan, R. Preisinger, D. Habier, R. Fernando, D. J. Garrick, and J. C. M. Dekkers. 2011. Persistence of accuracy of genomic estimated breeding values over generations in layer chickens. Genet. Sel. Evol. 43:23.

Wright, A. D. G., and A. V. Klieve. 2011. Does the complexity of the rumen microbial ecology preclude methane mitigation? Anim. Feed Sci. Technol. 166-67:248-253.

Yin, T., T. Pinent, K. Brugemann, H. Simianer, and S. Konig. 2015. Simulation, prediction, and genetic analyses of daily methane emissions in dairy cattle. J. Dairy Sci. 98:5748-5762.

Yu, J., G. Pressoir, W. H. Briggs, I. V. Bi, M. Yamasaki, J. F. Doebley, M. D. McMullen, B. S. Gaut, D. M. Nielsen, J. B. Holland, S. Kresovich, and E. S. Buckler. 2006. A unified mixed-model method for association mapping that accounts for multiple levels of relatedness. Nat. Genet. 38:203-208.

Zebeli, Q., J. R. Aschenbach, M. Tafaj, J. Boguhn, B. N. Ametaj, and W. Drochner. 2012. Invited review: Role of physically effective fiber and estimation of dietary fiber adequacy in high-producing dairy cattle. J. Dairy Sci. 95:1041-1056. 